\title{
The Effectiveness of Time Token Learning Model for Elementary School Students
}

\author{
Izzatul Lailah Wijayanti, Aminuddin Kasdi, Suhanadji \\ State University of Surabaya \\ Surabaya, Indonesia \\ izzatulwijayanti16070855056@mhs.unesa.ac.id
}

\begin{abstract}
- the study aims at evaluating the effectiveness of time token learning model implementation to increase critical thinking skills for elementary school students based on students' activities and lesson plan implementation. The data were collected through observation by using research diary and observation sheet. The participants were two classes of elementary students in SDN Panjunan, Sukodono, Sidoarjo, East Java. The study found that the Time Token was effective in terms of two parameters. The first parameter was the students' activities which showed that the students were actively engaged during the teaching and learning process. Their activities were dominantly about arguing, solving problem, and collaborating. The second parameter was the lesson plan implementation in which the result described that all of phases in the Time Token Learning Model were implemented in good and very good level. In other words, the evaluation result of the model was effective for implementing such learning model in Elementary school.
\end{abstract}

Keywords - time token; elementary school students; students' activities; lesson plan implementation

\section{INTRODUCTION}

Education is a human effort to create qualified individuals/individuals. The key to make this happen is by improving the quality of education. In other words, the quality of education is a measure of the quality of the nation itself. The Government has defined the function of National Education in the provisions of Law Number 20 Year 2003 on National Education System of Indonesia. The clause 3 of the law states that National Education functions to develop the ability and form the character and civilization of the dignified nation in order to educate the nation's life, the potential of learners to become human beings who believe and piety to God Almighty, as well as to have a noble character who are healthy, knowledgeable, capable, creative, independent, and also become citizens of a democratic and responsible citizens.

In line with the law, teachers are the key to the success of national education. Teachers can be defined as professionals who serve as educators, teachers, mentors, directors, trainers, assessors, and evaluator of learners. Thus, teachers should always innovate and be creative in designing a learning process, so that the learning that is designed is innovative and fun for the students.

One of the educational levels that plays an important role for creating the quality of human resources is elementary education [1]. Based on the results of observations at SDN (Elementary School) Panjunan Sukodono Sidoarjo, the implementation of Social Science Education learning, especially on the material of ethnic diversity and Indonesian culture that occurred, was not optimal. The students still faced difficulties in understanding the concept given. The factors that cause it, is the method or the learning model, in which the teacher still had domination in the process of students' learning in the classroom. In addition, the applied learning model was less varied and less enjoyable. The students were still served with the process of learning with rote and readings. Therefore, their responses during the lesson were less active and quickly saturated when the learning was taken place.

In addition, it was supported by interviews with $5^{\text {th }}$ grade social sciences' teachers with 5-year teaching experience. The results of those interviews revealed that the students were less active during the learning and the students' abilities in analyzing the problems related to the subject were still low. In addition, the teachers stated that the students still had a high dependence on the teachers. They learned only from what the teacher gave. Moreover, the learning resources used by teachers were still dominated by exercise questions on worksheet or textbooks. The students were only actively listening to what the teacher was saying, without learning by themselves in order to bring up ideas in their mind. It made the students passive and have lower thinking skills [2].

Dealing with the existence of problems on the condition of learning activities in the classroom, it is necessary to have an application of learning models that are innovative and fun for students. The Time Token Learning Model is one of the learning models that fulfills these two core elements: innovative and fun. According to Eliyana, as cited in [3], she states that the Time Token Model is one type of cooperative learning model that conditions students in groups, with the aim to stimulate social skills and make students actively discuss. After the students are conditioned in groups, the teacher presents the material and is followed up by the students through group assignments. The task serves as an effort of the teacher for helping all group members to understand the provided learning materials. Then, the teacher prepares a test for the students' evaluation as the end.

There were several relevant studies related to the use of the Time Token Model. One of them is the research that has been done is in [4] which was done by applying Cooperative 
Learning Model with Type of Time Token. The study focused on improving students' understanding of the topic of globalization by applying the Time Token Learning Model. The results showed that the learning model was able to improve students' understanding of the fourth grade of SD (Elementary School) Angkasa Colomadu, Karanganyar. In addition, reference [5] has conducted research to determine the effect of applying Time Token Learning Model to student learning outcomes. The subjects of the study were the students of Year 5 in SD Gugus II of Seririt Sub-district on Civics Subject. The results of the study also indicated an improvement in learning outcomes after the application of the Time Token learning model.

Based on the discussion above, the researcher will evaluate the implementation of Time Token learning model for elementary school students based on two parameters, that are, students' activities and lesson plan implementation.

\section{METHODS}

\section{A. Research Design}

The research design was a mixed methods combining quantitative and qualitative data [6]. Specifically, the type was a triangulation of mixed methods designs [7],[8],[9],[10]. The design is pictured in Figure 1 below.

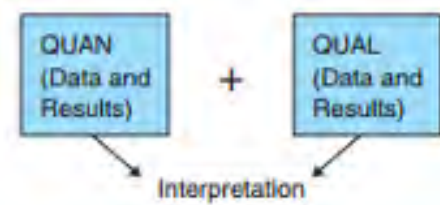

Fig 1. The design of mixed methods triangulation [6]

The Figure 1 describes that the quantitative and qualitative data are combined and integrated each other to construct an interpretation. The research used two classes involving an experimental and a control class.

The research involved a control class and an experiment class. Didactic teaching treated the control class. Meanwhile, the other class, the experimental class, used Time Token Learning Model [11],[12],[13]. The syntax of the learning model consisted of six phases including phase one of clarifying goals and establishing set, phase 2 of presenting information, phase 3 of organizing students into learning teams, phase 4 of assisting teamwork and study, phase 5 of testing on the materials, and phase 6 of provide recognition [14].

\section{B. Participants}

The participants were two classes of elementary students in SDN Panjunan, Sukodono, Sidoarjo, East Java. The sampling technique used was purposive sampling [15]. They samples consisted of 24 students of Year 5 of Elementary school.

\section{Data Collecting Technique}

The data were collected by observing the students' activities and the implementation of lesson plan. The instrument for observing the activities was a research diary [16], [17], [18], [19]. Through that way, the researcher noted all the students' activities showed during their learning in the class. For observing the lesson plan implementation, the researcher used an observation sheet. The sheet was constructed based on the syntax of learning model.

\section{Data Analysis Technique}

In order to reach the research aim, there were three steps to process the data that had been collected through involving collecting, simplifying and categorizing, comparing, and consolidating. The steps were a modification of analyzing data technique for mixed method study as in [6].

\section{RESULTS AND DISCUSSION}

This part is provided to examine the effectiveness of Time Token Learning Model implementation according to the two parameters involving students' activities and lesson plan implementation. Each parameter will be evaluated in more detail explanation below.

\section{A. Students' Activities}

The students' activities were shaped through the syntax of Time Token Learning Model with six phases. The six phases involved phase one of clarifying goals and establishing set, phase 2 of presenting information, phase 3 of organizing students into learning teams, phase 4 of assisting teamwork and study, phase 5 of testing on the materials, and phase 6 of provide recognition. The identical activities of the Time Token Learning Model occurred in phase 4 in which there were activities related to the question cards.

Generally, the set of phase 4 consisted of three steps. The first step was that the class was constructed into a discussion set. Secondly, the teacher provided talking cards to the students. The students had to answer the question from the card for 30 seconds. The last step was that the cards that were not finished yet, had to be continued to answer the questions.

Based on the observation, there were three dominant activities occurred during the learning process in the experiment class. The students were arguing, solving problem, and collaborating. The three main activities are elaborated below.

\section{1) Arguing}

The students were forced to communicate their idea to their own groups and in front of the class. They showed positive responses to the condition, as noted in the research diary below.

RD. Note 1: "almost all students are very active to participate in terms of sharing ideas as seen in Figure 2." 


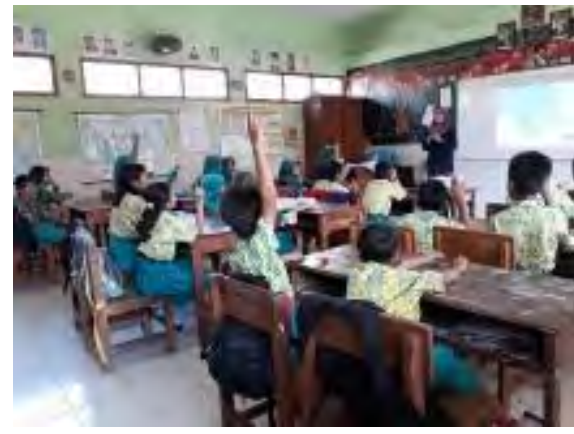

Fig 2. Partcipations of Students

RD. Note 3: "all groups of the students discuss the answer of questions to their own group actively as seen in Figure 3."

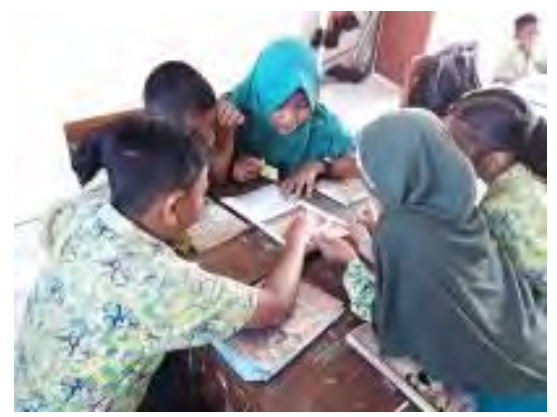

Fig 3. Discussion for Answering Questions

RD. Note 15: "each group shares ideas in front of the class as seen in Figure 4."

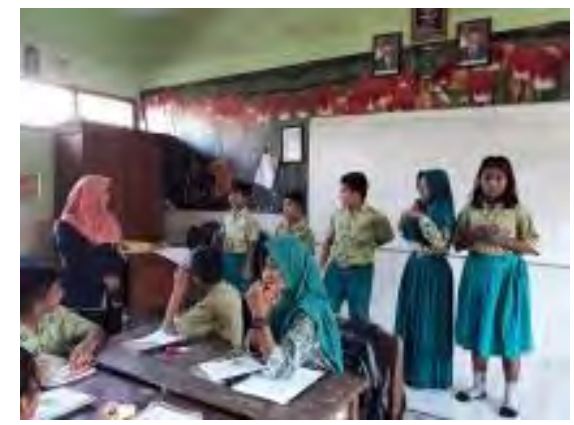

Fig 4. Sharing Idea in front of The Class

Through the activities, the class becomes more active. The learning model has been successful to force the students to take a role as the center of learning.

\section{2) Solving Problems}

One of the Time Token Learning Model characteristics is that the students were provided cards containing questions. The questions were related to the cultures in Indonesia, such as Ludruk, Wayang Kulit, and Remo Dance. They had to describe the condition and position of the culture in their society. Then, they were forced to propose alternative ways to conserve the culture. They tried to explain the solutions for the problem of culture happened in the society.

The students actively answered the questions embedded in the cards, as written in the diary coded RD. Note 5, 6, and 8.
RD. Note 5: "each group is working to solve the questions provided in the cards."

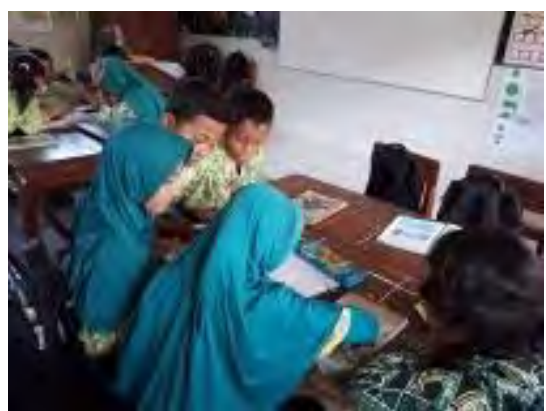

Fig 5. Solving Questions in The Cards

RD. Note 6: "they seem enthusiastic with their own groups to find out the solution for each problem in the cards as seen in the Figure 3 and 5.'

RD. Note 8: "the students are able to answer the questions, for example: what is the solution you propose to keep a traditional art like Ludruk in the Figure 3 and 5."

In other words, through this model, the students had learned to stimulate their problem-solving skills.

\section{3) Collaborating}

The phase 3 , organizing students into learning teams, was the condition during the students' learning. Here, each group consisted of 5 members. They interacted each other enthusiastically They shared their ideas in their own group and other groups, as mention in the notes below.

RD. Note 4: "the students are divided into groups as seen in Figure 6."

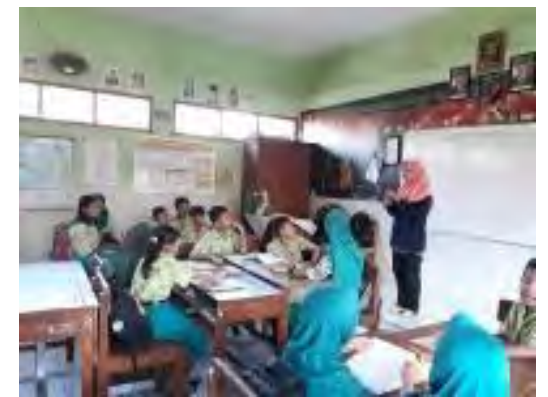

Fig 6. The Students in groups

RD. Note 5: "each group is working to solve the questions provided in the cards as seen in the Figure 5."

RD. Note 6: "they seem enthusiastic with their own groups to find out the solution for each problem in the cards as seen in the Figure 3."

RD. Note 7: "students with higher performance help the others as seen in Figure 7."

Based on the observation, the scaffolding happened through their own friends. The students worked to reach their Zone Potential Development. Therefore, their performance had increased through such collaboration activities. 


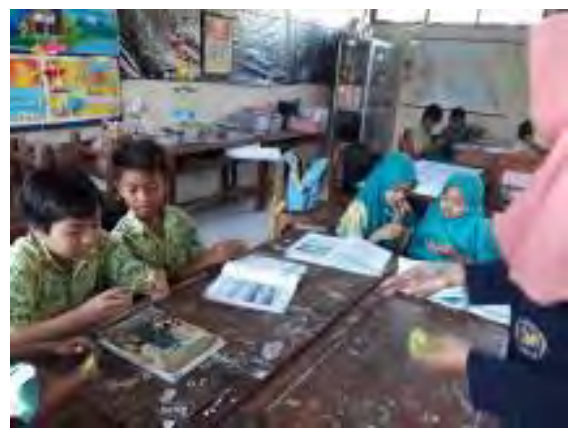

Fig 7. The Students Helping Each Others

\section{B. Lesson Plan Implementation}

This discussion was constructed to evaluate how far the lesson plan was successfully and completely implemented in the experimental class. In other words, the result of this observation is as a mirror the quantity and the quality of the lesson plan implementation. The result of the observation was presented in Table 1.

TABLE I. OBSERVATION RESUltS OF LESSON PLAN IMPLEMENTATION

\begin{tabular}{|l|c|c|}
\hline \multicolumn{1}{|c|}{ Phase of the learning } & $\begin{array}{c}\text { Average } \\
\text { Score }\end{array}$ & $\begin{array}{c}\text { Level/ } \\
\text { Category }\end{array}$ \\
\hline Phase 1: Clarifying goals and establish set. & 3 & Good \\
\hline Phase 2: Presenting information. & 4 & Excellent \\
\hline $\begin{array}{l}\text { Phase 3: Organizing students into learning } \\
\text { teams. }\end{array}$ & 4 & Excellent \\
\hline Phase 4: Assisting teamwork and study. & 3.5 & Excellent \\
\hline Phase 5: Testing on the materials. & 4 & Excellent \\
\hline Phase 6: Providing recognition. & 3.5 & Excellent \\
\hline
\end{tabular}

(Criteria: $1.00-1.99=$ Unacceptable; $2.00-2.99=$ Need improvement; $3.00-3.49=$

Good; $3.50-4.00=$ Excellent as in [20])

The Table 1 informs that all the phases were implemented with excellent and good level. In other words, the teacher was successful to bring Time Token Learning Model to the class. On the other hand, the phase 1 still needs to be concerned for further implementation of lesson plan, especially dealing motivating the students. It might affect the students' learning.

\section{The Effectiveness of Time Token Learning Model}

There were two parameters to describe the effectiveness of Time Token Learning Model, that were, the students' activities and the lesson plan implementation. The two parameters showed positive results. In other words, the learning model affected students' activities in positive way, and was successfully implemented during the teaching and learning process.

The positive activities involved arguing, solving problem, collaborating activities. The three activities were the indicator of an active learning.

Argumentation activities are able to stimulate a decisionmaking ability of student [21],[22]. In addition, the activity will help the students to achieve higher their performances and outcomes [23]. One of the factors, which is able to promote the argumentation skills of students, is the role of the teacher in facilitating whole class discussion [22].

The problem-solving skills is one of the main learning outcomes of the current education. Other researchers were also in line that many strategies have been implemented to increase students' problem-solving skills [24],[25],[26], [27]

Reference [28] and [29] revealed the shared responsibility and interaction produce more positive feelings toward tasks. In addition, a collaborative learning has a big possibility to enhance critical thinking [30] [31].

In addition, lesson plan is an essential part of teaching. In line with reference [32],

"lesson plan is a written description of education process in which it is shown what, when, where and with which method learners should learn and how they should be assessed. Lesson plan is one of the key factors in the educational process."

\section{CONCLUSION}

In conclusion, the implementation of Time Token Learning Model was effective for elementary school students based on the two parameters, namely, students' activities and lesson plan implementation. The learning model had successfully stimulated the students to be active learners that were expressed through arguing, solving problem, and collaborating activities. In addition, the lesson plan procedures were practiced that was proven by the result of observation. The result described that the phases of syntax were implemented in good and excellent level of category.

\section{ACKNOWLEDGMENT}

The researcher expresses gratitude towards Elementary Education Department for Master Degree that have provided literature for helping constructing the article, and also towards Panjunan Elementary School (SDN Panjunan) as place to conduct the study as well as dealing with participants of the research. Moreover, the family of the first author was the funder of conducting this research.

\section{REFERENCES}

[1] D. M. Hoffman, "Pedagogies of Self in American and Japanese Early Childhood Education: A Critical Conceptual Analysis", The Elementary School Journal, Vol. 101(2), p. 193-208, 2000.

[2] N. Michel, J. J. Cater III, and O. Varela, "Active versus passive teaching styles: An empirical study of student learning outcomes", Human Resource Development Quarterly, Vol. 20(4), p. 397-418, 2009.

[3] A. Shoimin, "68 Model Pembelajaran Inovatif dalam Kurikulum 2013," Yogyakarta: Ar-Ruz Media, 2014.

[4] T. Wahyuni, A. Dakir, and P. Rintayani, "Penerapan Model Pembelajaran Kooperatif Tipe Time Token untuk Meningkatkan Pemahaman Tentang Globalisasi”, Surakarta: Universitas Sebelas Maret, 2013.

[5] Valentina, O. Febrayani, Nym. Jampel, and I. Nym. Murda, "Pengaruh Model Pembelajaran Time Token Terhadap Hasil Belajar PKn Siswa Kelas V SD Gugus II Kecamatan Seririt", Singaraja: Universitas Pendidikan Ganesha, 2013. 
[6] L.R. Gay, G. E. Mills, and P. Airasian, "Educational Research: Competencies for Analysis and Applications", 10 ${ }^{\text {th }}$ ed, USA: Pearson, 2012, pp. 486-487.

[7] D. M. Mertens and S. Hesse-Biber, "Triangulation and Mixed Methods Research: Provocative Positions", Journal of Mixed Methods Research, Vol. 6(2), p. 75-79, 2012.

[8] S. Mathison, "Why Triangulate?", Educational Researcher, Vol. 17(2), p. 13-17, 1988.

[9] M. Sandelowski, "Combining Qualitative and Quantitative Sampling, Data Collection, and Analysis Techniques in Mixed-Method Studies", Research in Nursing and Health, Vol. 23(3), p. 246-255, 2000.

[10] T. D. Jick, "Mixing Qualitative and Quantitative Methods: Triangulation in Action", Administrative Science Quarterly, Vol. 24(4), Qualitative Methodology, p. 602-611, 1979.

[11] R. Fentari and S. L. D., “The Influence of Using Time Token Method Toward Speaking Ability at the Students of SMPN 1 Batanghari Academy Year 2014/2015", Premise Journal, Vol. 5(1), p.117-129, 2016.

[12] H. Fanani and J. A. Pramukantoro, "Pengaruh Teknik Pembelajaran Kooperatif Tipe Time Token Arends Terhadap Hasil Belajar Siswa pada Mata Diklat Dasar-dasar Kelistrikan di SMKN 1 Sidoarjo", Jurnal Pendidikan Teknik Elektro, Vol. 2(2), p. 829-836, 2013.

[13] A. Wiyarsi, "Implementation of Cooperative Learning Type Time Token to Increase the Students Activitiy and Interest Learning on General Chemistry", Prosiding Seminar Nasional Kimia dan Pendidikan Kimia 2010, ISBN 978-979-98117-7-6.

[14] T. Y.E. Siswono, "Mengajar \& Meneliti: Panduan Penelitian Tindakan Kelas untuk Guru dan Calon Guru”, Surabaya: Unesa University Press, 2008.

[15] Sugiyono, "Metode Penelitian Pendidikan Kuantitatif, Metode Kualitatif, dan R\&D”, Bandung: Alfabeta, 2010.

[16] K. A. Clarke, "Uses of a Research Diary: Learning Reflectively, Developing Understanding and Establishing Transparency", Nurse Researcher, Vol. 17(1), p.68-76, 2009.

[17] M. Engin, "Research Diary: A Tool for Scaffolding", International Journal of Qualitative Methods, Vol. 10(3), p.296-306, 2011.

[18] S. Nadin and C. Cassell, "The use of a research diary as a tool for reflexive practice: Some reflections from management research", Qualitative Research in Accounting \& Management, Vol. 3(3), p.208$217,2006$.
[19] R. C. Fraley and N. W. Hudson, "Review of Intensive Longitudinal Methods: An Introduction to Diary and Experience Sampling Research", The Journal of Social Psychology, 154, p.89-91, 2014.

[20] S. Arikunto, "Dasar-dasar Evaluasi Pendidikan”, Jakarta: Bumi Aksara, 2011

[21] T. Patronis, D. Potari, and V. Spiliotopoulou, "Students' argumentation in decision-making on a socio-scientiÒc issue: implications for teaching", International Journal of Science Education, Vol. 21(7), p. 745-754, 1999.

[22] V. M. Dawson and G. Venville, "Teaching Strategies for Developing Students' Argumentation Skills About Socioscientific Issues in High School Genetics", Research in Science Education, Vol. 40(2), p. 133 $148,2010$.

[23] S. Okumus and S. Unal, "The Effects of Argumentation Model on Students' Achievement and Argumentation Skills in Science", ProcediaSocial and Behavioral Sciences, Vol. 46, p. 457-461, 2012.

[24] P. Heppner, G. Neal, and L. Larson, "Problem-solving Training as Prevention with College Students, Personnel and Guidance Journal, Vol. 62, p. 514-519, 1984.

[25] R. Nickerson, D. Perkins, and E. Smith, "The Teaching of Thinking," Hillsdale, New Jersey: Lawrence Erlbaum Associates, 1985.

[26] J. Stice, (Ed.), "Developing Critical Thinking and Problem-solving Abilities. San Francisco: Jossey-Bass, 1987.

[27] A. Whimbey, and J. Lochhead, "Problem Solving and Comprehension", 3rd ed, Philadelphia: Franklin Institute Press, 1982.

[28] B. Joyce and M. Weil, Models of Teaching, 4th ed, USA: Allyn and Bacon, 1992.

[29] W. Rau, and B. S. Heyl, "Humanizing the College Classroom: Collaborative Learning and Social Organization Among Students, Teaching Sociology, Vol. 18, p. 141-155. 1990.

[30] A. A. Gokhale, "Collaborative Learning Enhances Critical Thinking", Journal of Technology Education, Vol. 7(1), p. 22-30, 1995.

[31] R. T. Johnson, and D. W. Johnson, "Action Research: Cooperative Learning in the Science Classroom. Science and Children, Vol. 24, p 31 32,1986 .

[32] A. J. Nesari and M. Heidari, "The Important Role of Lesson Plan on Educational Achievement of Iranian EFL Teachers' Attitudes", International Journal of Foreign Language Teaching \& Research - Vol. $3(5)$, p. $25-31,2014$ 